\title{
Percutaneous catheter erosion and enteric fistula formation after intervention for perforated appendicitis
}

\author{
Shinban Liu, ${ }^{1}$ Joseph Costa, ${ }^{2}$ George Ferzli ${ }^{1}$
}

${ }^{1}$ General Surgery, NYU Langone Medical Center, Brooklyn, New York, USA

${ }^{2}$ General Surgery, Staten Island University Hospital, Staten Island, New York, USA

Correspondence to Dr Shinban Liu,

shinban.liu@nyumc.org

Accepted 8 August 2018
Check for updates

(c) BMJ Publishing Group Limited 2018. No commercial re-use. See rights and permissions. Published by BMJ.

To cite: Liu S, Costa J, Ferzli G. BMJ Case Rep Published Online First: [please include Day Month Year]. doi:10.1136/bcr-2018 227045

\section{DESCRIPTION}

A 73-year-old man with a medical history of hypertension, hyperlipidaemia and previous laparoscopic cholecystectomy presents with vague and diffuse dull abdominal pain associated with diarrhoea for 2 weeks. His symptoms were not associated with nausea, vomiting, anorexia, fevers or chills. Laboratory values were significant for a leucocytosis of $18 \mathrm{~K} / \mu \mathrm{L}$. A CT of the abdomen and pelvis with contrast revealed a complex, phlegmonous collection in the right lower quadrant measuring $6.5 \times 4 \times 5 \mathrm{~cm}$ and associated reactive caecal wall thickening consistent with perforated appendicitis (figure 1A). The patient was started on broad-spectrum intravenous antibiotics (Cefepime and Flagyl) and underwent percutaneous drainage with Interventional Radiology where $30 \mathrm{~mL}$ of purulent fluid was aspirated and a 12 Fr drainage catheter was left in place. He remained stable post-procedure with resolution of his leucocytosis and was discharged to a skilled nursing facility on hospital day 7 with the drainage catheter and a peripherally inserted central line for continued intravenous antibiotics. Arrangements were made for interval appendectomy after resolution of acute inflammation and colonoscopy with close observation of the drain output. Approximately 6 weeks after catheter placement, the patient noticed sudden development of malodorous and

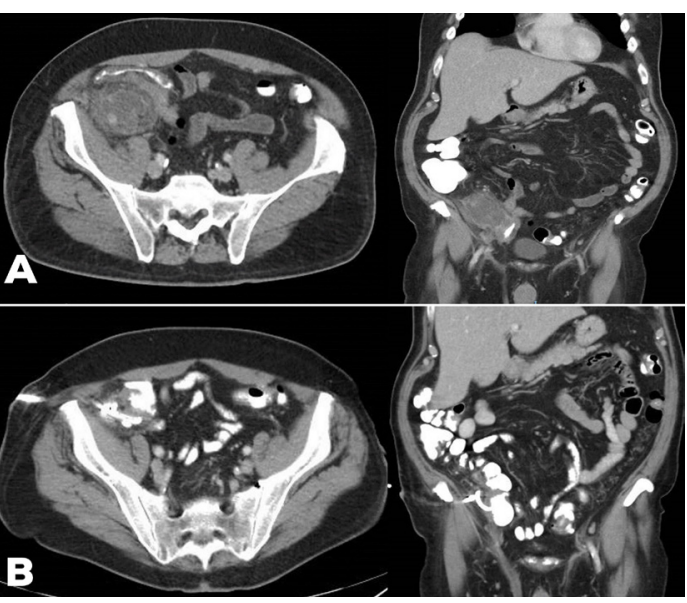

Figure 1 (A) CT of the abdomen and pelvis demonstrating complex, phlegmonous collection in the right lower quadrant measuring $6.5 \times 4 \times 5 \mathrm{~cm}$ and associated reactive caecal wall thickening consistent with perforated appendicitis. (B) CT of the abdomen and pelvis with confirmed position of the drainage catheter; no significant residual collection and interval improvement in previously noted inflammatory changes.

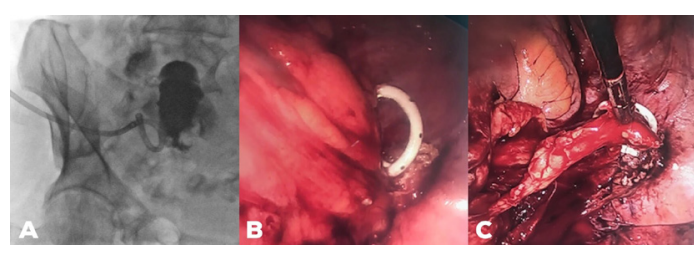

Figure 2 (A) Fluoroscopic contrast-enhanced drain study with visualised fistulisation from the drain to the caecum. (B) Intraoperative image of drainage catheter eroding into the wall of the caecum. (C) Surgical dissection and removal of the catheter prior to hemicolectomy.

feculent drainage. Imaging at this time demonstrated proper positioning of the drain with no significant residual collection and interval improvement in previously noted inflammatory changes (figure $1 \mathrm{~B}$ ). Due to clinical suspicion, a drain study was obtained with confirmation of fistulisation from the drain to the colon (figure 2A). The patient was brought to the operating room for diagnostic laparoscopy and was found to have erosion of the drainage catheter into the caecum (figure 2B,C). A laparoscopic right hemicolectomy was performed with primary anastomosis. His postoperative course and recovery was unremarkable.

Appendicitis is a common medical diagnosis that requires intervention. In patients with uncomplicated acute appendicitis, the treatment of choice for infectious source control is immediate appendectomy. However, patients with appendicitis complicated by perforation and abscess may be treated with broad-spectrum intravenous antibiotics and imaging-guided percutaneous drainage. ${ }^{1}$ This approach allows for resolution of the initial inflammatory process and may be followed by elective interval appendectomy or conservative non-operative management in select cases. However, as this case has demonstrated, non-surgical management of appendicitis is not without risks. Once a non-operative approach has been adopted, the patient is committed to a course of therapy with a distinct set of complications including multiple surveillance imaging studies (risk of radiation exposure), prolonged course of antibiotics (risks of developing resistance and Clostridium difficile infection), peripherally inserted central catheters (risks of thrombosis and infection) and catheter-directed drainage (risk of direct damage to surrounding structures or delayed complications such as this case). While large published series have demonstrated the safety and efficacy of percutaneous drainage for the treatment of complicated appendicitis with less than 
$5 \%$ incidence of complication, it is important for clinicians to be cognisant of potential risks and benefits in their decision-making. ${ }^{2}$

\section{Learning points}

- Uncomplicated acute appendicitis is preferentially treated with appendectomy.

- Appendicitis complicated by perforation and abscess may be treated with imaging-guided percutaneous drainage followed by elective interval appendectomy.

- Non-operative management of appendicitis is not without risk and, while rare, significant complications may arise.
Contributors JC and GF contributed to the management of this patient. SL and GF contributed equally to the drafting and editing of this manuscript.

Funding The authors have not declared a specific grant for this research from any funding agency in the public, commercial or not-for-profit sectors.

Competing interests None declared.

Patient consent Obtained.

Provenance and peer review Not commissioned; externally peer reviewed.

\section{REFERENCES}

1 Lasson A, Lundagårds J, Lorén I, et al. Appendiceal abscesses: primary percutaneous drainage and selective interval appendicectomy. Eur J Surg 2002:168:264-9.

2 Flancbaum L, Nosher JL, Brolin RE. Percutaneous catheter drainage of abdominal abscesses associated with perforated viscus. Am Surg 1990:56:52-6.

Copyright 2018 BMJ Publishing Group. All rights reserved. For permission to reuse any of this content visit

http://group.bmj.com/group/rights-licensing/permissions.

BMJ Case Report Fellows may re-use this article for personal use and teaching without any further permission.

Become a Fellow of BMJ Case Reports today and you can:

- Submit as many cases as you like

- Enjoy fast sympathetic peer review and rapid publication of accepted articles

Access all the published articles

Re-use any of the published material for personal use and teaching without further permission

For information on Institutional Fellowships contact consortiasales@bmjgroup.com

Visit casereports.bmj.com for more articles like this and to become a Fellow 